\title{
Academic Library Regional Accreditation
}

\section{Mary F. Casserly}

The self-study documents of fou academic libraries whose experiences with the regional accreditation self-study process ranged from unsuccessful to successful were analyzed. All four reports were predominantly descriptive and focused on processes. The successful sites employed user or expert opinion as types of assessments in their reports. No relationships were found between success and the resources, capabilities, products, services, and classes of evaluation addressed, the number of assessment measures included, or the extent to which association standards were addressed. The libraries' annual reports were found to contain more quantitative assessments of processes and outputs than the self-study reports.

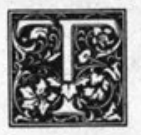

he vast majority of academic libraries are regularly involved, albeit to varying degrees, in the voluntary, nongovernmental process known as regional accreditation. Unfortunately, library administrators preparing for an impending accreditation review must rely almost exclusively on previous experience for guidance. There has been little research on the library's role in, or response to, either the self-study or the peer review aspects of the accreditation process.

The purpose of this article is to: (1) describe the contents of the regional accreditation self-study reports prepared by four academic libraries that experienced different degrees of self-study success; (2) characterize these reports by comparing them to each other, to the libraries' annual reports, and to their regional accrediting association guidelines; and (3) suggest some implications for academic libraries and their regional accrediting associations.

\section{BACKGROUND}

The process of qualifying for association membership, i.e., of being accredited, is identical for all six regional accrediting as- sociations. All prospective member institutions are required to conduct an institutional self-study. This phase of the accrediting process is then followed by review by a peer evaluation team consisting of faculty and educational administrators and other specialists from outside the institution. Members of the peer evaluation team examine the document prepared as a result of the self-study process, visit the institution, and report their findings to the accrediting association. The decision to accept an institution for membership is then made by the association on the basis of the self-study document, the peer evaluation team's report, and the institution's response to that report.

The self-study process is intended by all six associations to serve as a means of fostering improvement and change. More specifically, its purposes are to: (1) help improve the institution and its programs; (2) incorporate ongoing, useful institutional research and self-analysis into programs and the institution; and (3) serve as the foundation for planning efforts. ${ }^{1} \mathrm{Al}-$ though the design of the self-study process is not mandated (and numerous patterns and forms of self-study used by institutions undergoing regional accredi-

Mary F. Casserly is head of collection development at the Sarah Byrd Askew Library, William Paterson College, Wayne, New Jersey 07470. 
tation have been identified by Paul Dressel, Herbert Kells, and Grover Andrews), all of the associations require that the process be described and documented in a self-study report. ${ }^{2,3,4}$ This report is then used by the peer evaluation team in its review of the institution and is intended for further use by the institution as part of its planning process.

Critics of the regional accreditation process abound. They have been quick to point out that the process as a whole is expensive and time-consuming ${ }^{5}$ and that in most institutions the self-study process does not become part of an ongoing, increasingly sophisticated planning process. $^{6}$ The self-study reports have been characterized as primarily descriptions of process ${ }^{7}$ and as mere public relations documents. ${ }^{8}$ Further, it has been charged that the criteria included in these guidelines do not insure institutional quality and that they are not grounded in research or theory."

Examinations of the six regional accreditation associations' literature indicate that the quality of the academic library is regarded as an important element in the overall excellence of the educational institution. ${ }^{10}$ However, few researchers have chosen to explore the library's involvement in the process by which such institutions demonstrate the quality of their programs. Early studies of the accreditation process by Alan Covey and Morris Gelfand, as well as those more recently conducted by Dudley Yates and Ronald Leach, have focused on the process by which the peer review team evaluates the library. ${ }^{11,12,13,14}$ With the exception, then, of Toni Kania's efforts to develop a model set of regional accreditation standards for academic libraries, ${ }^{15}$ the academic library's involvement in the institution's preparation for regional accreditation has been virtually unexplored.

\section{DESCRIPTION OF THE STUDY}

The data reported in this article were collected as part of doctoral research completed in $1983 .{ }^{16}$ The purpose of this research was to investigate planned change processes in academic libraries and to identify factors associated with the suc- cess of one type of planned change process, the self-study. Employing a casestudy methodology, this study compared and contrasted the self-study experiences (including the resulting reports) of two relatively successful and two relatively unsuccessful regional library self-study processes related to regional accreditation. The study relied heavily on interview data and required on-site visits by the researcher. For this reason the case-study sites were selected from those institutions in the Middle States and Northeastern accrediting associations, located in the regions most accessible to the researcher.

The selection of the case-study sites began with the examination of the recently completed institutional self-study documents from institutions of higher education in two regional accrediting associations. The directors of those libraries that, judging from the contents of these reports, had played active roles in their institutions' self-study processes were subsequently interviewed, and a brief profile of each library's self-study process was then constructed. Using these profiles, the libraries were then classified into groups ranging from "good" to "poor," according to the level of librarian involvement in the self-study process, the number and magnitude of changes or improvements that were reported as resulting from the process, the sophistication of the performance and other measures included in the self-study report, and the availability of the data needed for the proposed study. Every effort was made to select sites that represented a wide variety of experience and differing levels of satisfaction with the self-study process.

The four medium-sized libraries that were eventually selected had 221,000 to 357,000 volumes in their collections and between ten and sixteen professional staff members. The enrollments of the institutions they served ranged from forty-five hundred to eighty-six hundred full-time and part-time students. Three of the institutions were accredited by the Middle States Association of Colleges and Secondary Schools, and one was a member of the New England Association of Colleges and Secondary Schools; three were pub- 
licly supported, and one was a private institution. At all of the institutions the master's was the highest degree offered.

The data were collected for this study using document analysis, and questionnaires and interviews that incorporated the factors included in Kells' desired attributes of self-study and Jack Lindquists' adaptive development model of planned change. ${ }^{17,18}$ The questionnaire and interview responses enabled the researcher to compare the case-study sites on the basis of the outcomes of the process: organizational changes and improvements, advice and recommendations for future actions, and benefits accruing to the libraries and librarians.

The comparisons of the outcomes of the four self-study processes confirmed the fact that the sites had indeed experienced differing degrees of self-study success. While librarians at two of the sites could associate few, if any, outcomes or benefits with the accreditation-related self-study process, librarians at the other two sites identified such outcomes as increased internal communications, better long-term planning, useful advice and recommendations, and a variety of improvements in specific areas of library performance. The librarians at these two sites also realized organizational and personal linkage and ownership benefits.

The difference in the extent to which the four sites realized outcomes and benefits from their self-study processes led to designating them as sites A, B, C, and D, with $A$ being the site where the fewest number of outcomes was realized and D, where the greatest number was realized. This continuum provides the frame of reference for comparing the reports of the four sites.

The reports generated at the sites were analyzed for the purpose of identifying the designs and procedures used during these self-study processes. To this end the following research questions were posed:

a. What types of performance measures were employed for the library segment of the institutional self-study?

b. Were these measures typical of the types of performance measures used by the libraries on an ongoing basis? c. How do the performance measures used in the library self-study relate to the standards or guidelines provided by their regional accrediting association?

The library self-study documents and annual reports were analyzed and then compared on the basis of the classes of evaluation, types of measurement assessments, and the specific resources, capabilities, products, services, and benefits that these documents addressed. In addition, each self-study document analysis was compared with an analysis of the statements on library standards issued by the appropriate regional accrediting association. Since neither the Middle States Association nor the New England Association recommends specific methods of measuring or assessing library performance, these statements on library standards could not be analyzed and compared with the libraries' self-study documents in terms of the types of measurement assessments employed.

The four classes of evaluation employed by John Knightly in his study of library annual reports (see table 1) did not have to be modified in order to employ them in this study. ${ }^{19}$ However, it was necessary to clarify the distinction between two of Knightly's types of assessments: assessment on the basis of "costs" and assessment on the basis of "quantifiable measures." These types proved difficult to apply during the document analysis because cost is a type of quantifiable measure. Therefore, as the measurement criteria listed in table 1 indicate, the seventh type of assessment in this study was called "other quantifiable measures," a category that included all quantifiable assessment measures with the exception of those expressed in monetary terms.

\section{RESULTS \\ Types of Performance Measures Employed in the Self-Study Documents}

The self-study documents pertaining to the case-study sites are presented in table 2 in terms of the classes of evaluation, the specific resources, capabilities, products, services, or benefits addressed, the type of assessments employed, and the amount of text devoted to each of these. 
TABLE 1

FOUR CLASSES OF EVALUATION AND SEVEN TYPES OF MEASUREMENT CRITERIA

\begin{tabular}{|c|c|}
\hline Classes of Evaluation & Examples of Resources, Capabilities, Products, Services, and/or Benefits Belonging to Each Class \\
\hline $\begin{array}{l}\text { Inputs (Resources) } \\
\text { Processes (Capability) }\end{array}$ & $\begin{array}{l}\text { Budget, Space, Salaries, Gifts } \\
\text { Methods, Collections, Security, Catalog, Cooperative Arrangements, Staff } \\
\text { Training, User Education, Policies, Planning/Organizing }\end{array}$ \\
\hline $\begin{array}{l}\text { Outputs (Utilization) } \\
\text { Impacts (Benefits) }\end{array}$ & $\begin{array}{l}\text { Uses of Services } \\
\text { Impact on objectives of parent organization-learning, company perfor- } \\
\text { mance, cost savings compared to use of alternate sources of information, } \\
\text { stimulation of invention or productivity, improved decisions, improved level } \\
\text { of education, better use of leisure }\end{array}$ \\
\hline $\begin{array}{l}\text { Types of Measurement } \\
\text { User opinion } \\
\text { Expert opinion } \\
\text { Ideal standards } \\
\text { Comparison with oth } \\
\text { Costs } \\
\text { Cost-effectiveness or } \\
\text { Other quantifiable m }\end{array}$ & $\begin{array}{l}\text { er organizations } \\
\text { cost-benefit relati } \\
\text { easures }\end{array}$ \\
\hline
\end{tabular}

TABLE 2

ANALYSIS OF SELF-STUDY REPORTS BY CLASS OF EVALUATION AND TYPE AND NUMBER OF ASSESSMENTS

\begin{tabular}{|c|c|c|c|c|}
\hline Site & $\begin{array}{c}\text { Class of } \\
\text { Evaluation }\end{array}$ & $\begin{array}{l}\text { Resources, Capabilities, } \\
\text { Products, Services, } \\
\text { Benefits Addressed } \\
\end{array}$ & $\begin{array}{c}\text { Description } \\
\text { or Type }(\xi) \text { of } \\
\text { Assessments Employed }\end{array}$ & $\begin{array}{l}\text { Lines } \\
\text { of Text }\end{array}$ \\
\hline \multirow[t]{4}{*}{ A } & Input & $\begin{array}{l}\text { Space, Staff } \\
\text { Space }\end{array}$ & $\begin{array}{l}\text { Description } \\
\text { Other quantitative }\end{array}$ & 16 \\
\hline & & Staff & $\begin{array}{l}\text { measures (2) } \\
\text { Comparison with }\end{array}$ & 4 \\
\hline & & Budget & $\begin{array}{l}\text { standaards }(2 \\
\text { Costs }(1)\end{array}$ & $\begin{array}{l}4 \\
6\end{array}$ \\
\hline & Process & Facilities and services, planning, allocation of library & Description & 164 \\
\hline
\end{tabular}

funds, user education, cooperative arrangements, selec-

tion of materials, collection, collection appropriateness

Facilities and use, collection adequacy

Collection size

User opinion (2) 6

Comparison with 7

Shelf capacity, seating capacity, availability of facility, Other quantitative 13 collection size

measures (4)

Output Collection and facility use

Description

Use of materials

Other quantitative 17

B Input Staff, budget

measures (3)

Description

Other quantitative 4

Budget

measures (1)

Costs (2)

Process Decision making, planning, staff development, renova- Description

tion of facility, typing facilities, hardware collection, user instruction, cooperative arrangements, collection development, cataloging, collection

Collection size, circulation process, accessibility of fac- Other quantitative ulty, audiovisual facilities, photocopying facilities, stu- measures (6) dent training

Service to handicapped, security

Expert opinion (2) 
TABLE 2 Continued

\begin{tabular}{|c|c|c|c|c|}
\hline$\underline{\text { Site }}$ & $\begin{array}{c}\text { Class of } \\
\text { Evaluation }\end{array}$ & $\begin{array}{c}\text { Resources, Capabilities, } \\
\text { Products, Services, } \\
\text { Benefits Addressed } \\
\end{array}$ & $\begin{array}{c}\text { Description } \\
\text { or Type }(f) \text { of } \\
\text { Assessments Employed } \\
\end{array}$ & $\begin{array}{l}\text { Lines } \\
\text { of Text }\end{array}$ \\
\hline \multirow[t]{4}{*}{ C } & Input & $\begin{array}{l}\text { Budget, staff } \\
\text { Budget } \\
\text { Staff } \\
\text { Space }\end{array}$ & $\begin{array}{l}\text { Description } \\
\text { Costs }(1) \\
\text { User opinion (1) } \\
\text { Other quantitative } \\
\text { measures (1) }\end{array}$ & $\begin{array}{r}13 \\
18 \\
5 \\
2\end{array}$ \\
\hline & Process & $\begin{array}{l}\text { Cataloging, collection development policy formulation, } \\
\text { selection of materials, cooperative arrangements, orga- } \\
\text { nization of library, security, multimedia facilities, reno- } \\
\text { vation of facility }\end{array}$ & Description & 76 \\
\hline & & Collection size & $\begin{array}{l}\text { Other quantitative } \\
\text { measures (1) }\end{array}$ & 3 \\
\hline & & $\begin{array}{l}\text { Collection, adequacy, cooperative arrangements, user } \\
\text { education }\end{array}$ & User opinion (4) & 18 \\
\hline \multirow[t]{12}{*}{ D } & Input & Budget, staff, gifts, space & Description & 79 \\
\hline & & Budget & Costs (1) & 3 \\
\hline & & Budget, staff, gifts & $\begin{array}{l}\text { Other quantitative } \\
\text { measures (4) }\end{array}$ & 14 \\
\hline & & Budget, staff & $\begin{array}{l}\text { Comparison with } \\
\text { standards (2) }\end{array}$ & 16 \\
\hline & & Budget, staff & User opinion (2) & 5 \\
\hline & & Budget, staff & Expert opinion (3) & 8 \\
\hline & Process & $\begin{array}{l}\text { Organization of library, user education, computerized } \\
\text { bibliographic services, cooperative arrangements, fund- } \\
\text { raising efforts, hardware collection, cataloging, collec- } \\
\text { tion accessibility, selection of materials, government } \\
\text { documents collection, archives and special collections, } \\
\text { audiovisual facilities, staff responsibility, and status }\end{array}$ & Description & 133 \\
\hline & & Library services, user education, collection quality & User opinion (5) & 21 \\
\hline & & $\begin{array}{l}\text { Collection quality and balance, planning, user educa- } \\
\text { tion, communication with academic departments }\end{array}$ & Expert opinion (4) & 14 \\
\hline & & $\begin{array}{l}\text { Seating capacity, curriculum collection, archives and } \\
\text { special collections, periodicals collection }\end{array}$ & $\begin{array}{l}\text { Other qualitative mea- } \\
\text { sures (4) }\end{array}$ & 12 \\
\hline & Outputs & Use of materials, use of curriculum center & Description & 10 \\
\hline & & $\begin{array}{l}\text { Use of curriculum center materials, use of library materi- } \\
\text { als }\end{array}$ & $\begin{array}{l}\text { Other quantitative } \\
\text { measures }(2)\end{array}$ & 5 \\
\hline
\end{tabular}

The self-study documents prepared at all sites included input and process classes of evaluation. Between two and four inputs were assessed and described in each report, and the process class of evaluation was given the greatest amount of attention in terms of both description and assessment. In all reports the capabilities and products assessed and described outnumbered the inputs plus outputs (if any) that were included.

Several processes were addressed by all of the sites: user education, cooperative arrangements (including interlibrary loans), and the collection (in terms of size). Three of the four documents included information on library planning activities (sites A, B, and D); cataloging processes (sites B, C, and D); selection of materials (sites A, C, and D); and either the circulating collection or the library collection in general (sites A, B, and D). A substantial number of processes were addressed by only one report.

The report prepared by sites A and D, the least and most successful sites, were the only self-study documents to include outputs. At site A the outputs addressed were the use of both the collection and the library building, while those at site $\mathrm{D}$ were 
the use of the materials in the library collection and the use of the curriculum center and its collection. None of the selfstudy reports addressed any aspects of the impact class of evaluation, i.e., the extent to which the library's accomplished objectives actually meet the needs of the institution.

An examination of the "classes of evaluation" column reveals that although a statement in the text of the document may have addressed a particular class of evaluation, it did not necessarily include a corresponding "type of assessment." In quantitative terms, these descriptive statements accounted for 78 percent of the total text of the library self-study document prepared at site A, 89 percent at site B, 61 percent at site $C$, and 68 percent at site D.

The number of assessments included in the documents ranged from a low of eight at site $\mathrm{C}$ to a high of twenty-eight at site $\mathrm{D}$. The only assessments employed by all of the sites were cost and other quantitative measures. Two of the sites, one relatively successful and one relatively unsuccessful, used standards to assess aspects of their organization. In both cases the standards used were those formulated by the American Library Association. It should be noted that at sites B and D, where expert opinion was employed as a type of assessment, the experts consulted were the librarians. None of the library reports included assessments of any aspects of their organizations based on the opinions of outside experts, nor did they include comparisons with other libraries, a type of assessment that Knightly ${ }^{20}$ found in the annual reports he studied.

More than 70 percent of the assessments used at the relatively unsuccessful sites A and B took the form of costs or other types of quantitative measures. However, these types accounted for less than 40 percent of the assessments included in the self-study documents prepared at the more successful sites $C$ and $D$, which relied heavily on user and expert opinion. User opinion accounted for 62.5 percent of the assessment measures were employed at site $C$ and 50 percent of those included in the self-study document prepared at site D.

\section{Comparisons of the Assessment \\ Measures Used in the \\ Self-Study and Annual Reports}

The annual reports generated at sites $\mathrm{A}$, $B$, and $C$ for several years prior to the accreditation-related self-study were examined in order to help determine whether the assessments included in the self-study reports were typical of those used by the libraries on an ongoing basis. It was not possible to examine the reports from site D because, prior to the recent accreditation-related self-study, it did not issue annual reports.

The self-study reports prepared by sites $A$ and $C$ contained a number of assessments of inputs that could not be found in their annual reports. At site $C$ these included user assessments of the need for more money to buy materials in specific subject areas and of staff professionalism, as well as a measurement of space. The self-study document presented at site A contained a comparison of the level of staffing with that recommended in the American Library Association standards and a description of staff qualifications. Neither of these appeared in any of its annual reports.

The annual reports generated at all three sites contained more detailed and numerous assessments of library processes than were addressed in the self-study documents. Most of the process assessments included in the annual reports and excluded from the self-study documents were quantitative assessments of such processes as cataloging, acquisitions of books and periodicals, binding, conversion to microforms, and interlibrary loan activities.

At each site, however, there were some assessments of processes that appeared in the self-study document but were not found in the annual reports. Examples include quantifications of shelf and seating capacities, number of volumes added to the collection since the last regional accreditation review, expert opinions of the director and/or librarians on the improvement in security and services to the handi- 
capped, and user opinions on collection adequacy, cooperative arrangements, and user education. All three of the self-study documents also contained many descriptions of processes not described in their annual reports. Among these were overviews of the various services and facilities available in the library and descriptions of methods used to select and classify materials and of organization and management structures.

In contrast to their self-study documents, the annual reports prepared at site $B$ and the more successful site $C$ did address outputs and contained quantitative assessments of them, including the number of uses for the facility and the number of materials circulated. Unlike sites B and C, outputs were included in the self-study document prepared at site $\mathrm{A}$, the least successful site. However, a larger number and more detailed presentation of outputs were found in this site's annual reports.

\section{The Regional Accreditation Standards and the Self-Study Documents}

Although the library guidelines formulated by the New England Association ${ }^{21}$ and the Middle States Association ${ }^{22}$ differ greatly in length and in the number and range of library resources, capabilities, products, services, and benefits they address, they are similar in several important ways. First, both sets of guidelines are qualitative rather than quantitative. Second, to a great extent both documents consist of general and often vague state- ments which, in order to infer the intent of the agency, require close analysis and extensive interpretation. Finally, neither agency's statements address the question of which methods or performance measures should be used by the library in order to determine the extent of its compliance with the guidelines. The classes of evaluation implied in these documents, as well as the resources, capabilities, products, services, and benefits they address, are summarized in table 3 .

Comparisons of tables 2 and 3 indicate that there was little difference between the way in which the New England Association standards were addressed by site B, and the ways in which sites A, C and D addressed the Middle States Association standards. Therefore, these comparisons can be summarized in terms of several generalizations. First, although the report prepared at site D, the most successful site, was the most comprehensive-in that it addressed at least one aspect of all the standards set by its regional accrediting association-the self-study reports prepared at the other sites included some aspects of all of the input standards and most of the process standards included in the guidelines set by their regional accrediting associations. Second, most of these input and process standards were addressed descriptively in the self-study reports. Third, only the reports prepared at . sites $A$ and D, which are at opposite ends of the self-study success spectrum, addressed the outputs included in the stan-

\section{TABLE 3}

CLASSES OF EVALUATION AND SPECIFIC RESOURCES, CAPABILITIES, PRODUCTS, SERVICES, AND BENEFITS ADDRESSED BY ACCREDITATION GUIDELINES

\begin{tabular}{|c|c|c|}
\hline $\begin{array}{l}\text { Accrediting } \\
\text { Association } \\
\end{array}$ & $\begin{array}{c}\text { Class of } \\
\text { Evaluation }\end{array}$ & $\begin{array}{l}\text { Resource, Capability, Product, } \\
\text { Service, or Benefit Addressed }\end{array}$ \\
\hline \multirow[t]{2}{*}{ New England } & Input & Staff qualifications; staff size \\
\hline & Process & $\begin{array}{l}\text { Collection availability, appropriateness, accessibility and arrangement; } \\
\text { study space availability; cooperation arrangements. }\end{array}$ \\
\hline \multirow[t]{3}{*}{ Middle States } & Input & $\begin{array}{l}\text { Staff experience, training and competence; budget adequacy; space; staff } \\
\text { philosophy of service. }\end{array}$ \\
\hline & Process & $\begin{array}{l}\text { Collection appropriateness, quality, balance and adequacy; cooperation } \\
\text { with faculty; staff responsibility and status; utilization of computerized } \\
\text { services; cooperative arrangements; organization of facility; facility } \\
\text { conditions and availability. }\end{array}$ \\
\hline & Output & $\begin{array}{l}\text { Effectiveness of general library operations; collection use; use of facility } \\
\text { for instructional purposes; general use of facility. }\end{array}$ \\
\hline
\end{tabular}


dards. And finally, the self-study documents prepared at all sites included some descriptions and assessments of processes that did not seem to pertain to any of the standards developed by their regional accrediting agencies. The most obvious of these are the descriptions and/or assessments of user education programs that appear in each of these reports.

\section{OBSERVATIONS}

The data from the analysis of the two regional accrediting associations' guidelines and the self-study and annual reports prepared at the case study sites suggest the following observations.

- The analysis of the classes of evaluation and the specific resources, capabilities, products, and services addressed in the self-study report seems to indicate that there is no relationship between the apparent success level of the self-study process conducted at the case study sites and these characteristics of their reports. Specifically, sites A and D, on opposite ends of the self-study success spectrum, addressed the widest variety of evaluation classes, i.e., inputs, processes and outputs. In addition, there do not seem to be any striking differences between those resources, capabilities, products and services included in the successful self-study process sites' reports and those addressed by the unsuccessful self-study process sites.

- It would seem that the reports of the more successful self-study processes, sites C and D, were less descriptive than the reports of the relatively unsuccessful sites. However, it should also be noted that all four of these reports were more than 60 percent descriptive.

- The finding that site $\mathrm{C}$ employed the smallest number of assessments and site D the largest indicates that among these sites there was no relationship between success of the self-study process and the number of assessments included in the reports.

- The analysis of the self-study reports indicates that the types of assessments employed during the self-study are related to the success of the self-study process. Specifically, the analysis revealed that the more successful sites in- cluded a higher percentage of user and expert opinions in their reports. The less successful sites relied more heavily on arbitrarily established criteria or standards from the profession, costs, and other quantitative measures as means of assessment. The experiences at these sites therefore suggest that assessments of various aspects of the library by experts, and especially users, can be a valuable technique for facilitating changes and improvements and for realizing other benefits from the selfstudy process.

- At each of the sites the annual reports were much richer sources of information than the self-study documents. This seems to be especially true with respect to quantitative assessments of library processes and outputs. This finding certainly seems contrary to what would logically be expected: the selfstudy document, which is intended to be a report of a concentrated period of self-evaluation, should have been more far-reaching and evaluative than the annual reports.

- The self-study documents generated at all of the sites contain descriptions of processes, many of them overviews of library services and functions that did not appear in the annual reports. This suggests that these reports were written as orientation and/or public relations documents for an outside audience, i.e., the evaluation teams, rather than as informative, candid assessments of library performance to be used by members of the library staff and college community.

- It does not appear that the extent to which the standards or guidelines established by the regional accrediting associations was addressed is related to the degree to which either improvements occurred in the libraries or librarians perceived that they benefited from their self-study experiences.

\section{CONCLUSIONS AND IMPLICATIONS FOR PRACTICE}

In summary, it can be said that despite the fact that the self-study processes conducted at these four sites varied in terms of the improvements, changes, and bene- 
fits accrued, their self-study reports were not very different. All were predominantly descriptive, focused on library processes and contained fewer and less detailed quantitative assessments of the libraries' processes and outputs than did their annual reports. Further, with the exception of their inclusion of user or expert opinion as types of assessments, the reports prepared at the relatively successful sites did not differ from those prepared at the relatively unsuccessful sites in terms of: classes of evaluation addressed; specific resources, capabilities, products, and services addressed; number of assessment measures included; or extent to which accrediting association standards were addressed.

As the description of the methodology of this study indicates, the libraries that served as case-study sites did not constitute a scientifically selected sample of academic library self-study processes. However, to the extent that these sites represent a cross section of self-study experiences, the findings of this study can be generalized to similar academic libraries and have implications for librarians and regional accrediting associations.

It is likely that supporters of the regional accreditation process will find the results of this study disturbing and discouraging. The public relations nature of these documents and their lack of candid assessments (relative to the annual reports) underscore the librarians' failure to report useful data on the effectiveness of the library to the accrediting associations. Whether this is the result of unwillingness, oversight, or failure on the part of the library and/or the institutional administration to understand or embrace the philosophy behind the regional accreditation process (and specifically the intention that the self-study process be a tool for im- provement and planning) remains to be determined.

The experiences at the four sites suggest that self-study reports typically do not address library outputs. Therefore, members of evaluation teams who rely heavily on them are in effect trying to evaluate the academic library's effectiveness and its achievement of goals largely on the basis of descriptions of its inputs and processes. This finding points out a need for informed evaluators who have been trained by the regional accrediting associations they represent to recognize the limitations of library self-study documents and to augment the information included in them. The findings study also suggest that user opinions of library performance and data from annual reports would be helpful to evaluators.

At the same time, the results underscore the academic library's need for more direction and support as it undertakes accreditation-related self-study. Because there appears to be no relationship between self-study success and the extent to which association guidelines or standards were addressed, it is incumbent upon these associations to develop guidelines or standards that provide more guidance to libraries willing to use the accreditationrelated self-study process as an opportunity for assessing effectiveness. This guidance would seem to be most beneficial if it were built on the preliminary work conducted by Kania ${ }^{23}$ and assisted practitioners in identifying and then actually applying appropriate performance measures. Additional sources of self-study assistance could be continuing education programs offered by library schools (such as those recently conducted by Kells and Kania at Rutgers University) and programs sponsored by various professional associations serving academic librarians and other educators.

\section{REFERENCES}

1. Herbert R. Kells, Self-Study Processes: A Guide for Post-Secondary Institutions (Washington, D.C.: American Council on Education, 1980), p.14-15.

2. Paul L. Dressel, "Accreditation and Institutional Self-Study," North Central Association Quarterly 46:277-87 (Fall 1971). 
3. Herbert R. Kells, "Institutional Accreditation: New Forms of Self-Study," Educational Record 53:143-48 (Spring 1972); and "An Alternative Model for Self-Study in Higher Education," North Central Association Quarterly 52:341-46 (Feb. 1977).

4. Grover J. Andrews, Non-Traditional Self-Studies in Accreditation, (U.S. Educational Resources Information Center, 1976, text-fiche), ED 118156.

5. R. C. Haywood, "The Mythus of Accreditation," The Educational Forum 38:228 (Jan. 1974); Rolf Larson, "Accreditation: Some Professional Problems," Learning Today 5:34 (Summer 1972); Stephen Romine, "Objectives, Objections, and Options: Some Perspectives of Regional Accreditation," North Central Association Quarterly 49:367 (Spring 1975).

6. Herbert R. Kells, "The Purposes and Legacy of Effective Self-Study Processes: Enhancing the Study-Planning Cycle," Journal of Higher Education 51:444 (July/Aug. 1980).

7. Herbert R. Kells, "The Reform of Regional Accreditation Agencies," Educational Record 57:26 (Winter 1976).

8. Eileen Rossi, "Accreditation Self-Study and Institutional Adaptability" (Ph.D. diss., Stanford Univ., 1979).

9. James D. Koerner, "Preserving the Status Quo," Change 3:52-53 (Mar./Apr. 1971); William E. Troutt, "Regional Accreditation Evaluative Criteria and Quality Assurance," Journal of Higher Education 50:209 (Mar./Apr. 1979).

10. Troutt, p.209; Herman L. Totten, Identification of Library Elements in Statements of Accrediting Standards: A Review of the Literature, (U.S. Educational Resources Information Center, 1974, text-fiche), ED 121350.

11. Alan Dale Covey, "Evaluation of College Libraries for Accreditation Purposes" (Ed.D. diss., Stanford Univ., 1955).

12. Morris A. Gelfand, "Techniques of Library Evaluators in the Middle States Association," College \& Research Libraries 19:305-20 (July 1958).

13. Dudley W. Yates, "An Analyses of the Bases Used by Library Evaluators in the Accrediting Process of the Southern Association of Colleges and Schools" (Ph.D. diss., Florida State Univ., 1973).

14. Ronald George Leach, "Identification and Modification of Criteria and Procedures for Evaluating Colleges and Universities by North Central Association Teams" (Ph.D. diss., Michigan State Univ., 1980).

15. Toni Kania, "The Development of a Model Set of Regional Accreditation Standards for Academic Libraries" (Ed.D. diss., Rutgers Univ., 1984).

16. Mary F. Casserly, "Self-Study and Planned Change in Academic Libraries: A Case Study Analysis of Regional Accreditation Self-Study Experiences" (Ph.D. diss., Rutgers Univ., 1984).

17. Kells, Self-Study Processes, p.16.

18. Jack Lindquist, Strategies for Change (Berkeley, Calif.: Pacific Soundings Pr., 1978), p.240-43.

19. John J. Knightly, "Overcoming the Criterion Problem in the Evaluation of Library Performance," Special Libraries 70:173-78 (Apr. 1979).

20. Ibid.

21. Commission on Institutions of Higher Education, Standards for Accreditation (Burlington, Mass.: New England Association of Schools and Colleges, 1979), p.6.

22. Commission on Higher Education, Characteristics of Excellence in Higher Education and Standards for Middle States Accreditation (Philadelphia, Pa.: Middle States Association of Colleges and Schools, 1978), p.15-17.

23. Kania, "The Development of a Model Set of Regional Accreditation Standards for Academic Libraries," 1984. 